IdeAs

Idées d'Amériques

$10 \mid 2017$

États-Unis / Cuba : une nouvelle donne?

\title{
Interview with Dr. Arturo Valenzuela on the United States-Cuba relationship
}

Isabelle Vagnoux

\section{OpenEdition}

\section{Journals}

Édition électronique

URL : https://journals.openedition.org/ideas/2230

DOI : 10.4000/ideas. 2230

ISSN : 1950-570

Éditeur

Institut des Amériques

Référence électronique

Isabelle Vagnoux, "Interview with Dr. Arturo Valenzuela on the United States-Cuba relationship », IdeAs [En ligne], 10 | 2017, mis en ligne le 12 janvier 2018, consulté le 20 octobre 2022. URL : http:// journals.openedition.org/ideas/2230 ; DOI : https://doi.org/10.4000/ideas.2230

Ce document a été généré automatiquement le 20 octobre 2022

\section{(c) (i) () $९$}

Creative Commons - Attribution - Pas d'Utilisation Commerciale - Pas de Modification 4.0 International - CC BY-NC-ND 4.0

https://creativecommons.org/licenses/by-nc-nd/4.0/ 


\title{
Interview with Dr. Arturo Valenzuela on the United States- Cuba relationship
}

\author{
Isabelle Vagnoux
}

Interview conducted by Dr Isabelle Vagnoux on September 9, 2017, with many thanks to Dr. Arturo Valenzuela for sharing his views with us.

Dr Arturo Valenzuela served in the State Department and the White House during the Clinton Administration and was Assistant Secretary of State for Western Hemisphere Affairs, during the Obama Administration from 2009-2011. A scholar, he was Professor of Government and Director of the Council on Latin American Studies at Duke University before joining the Georgetown Faculty in 1987 where he directed the Center for Latin American Studies in the Edmund A. Walsh School of Foreign Service at Georgetown University, Washington, D.C.

Would you say that the Clinton Administration's policy toward Cuba, somewhat but not totally reversed during the Bush Administration, paved the way for President Obama's Cuba policy?

I joined the State Department at the beginning of the Clinton Administration where I became responsible for the diplomatic relationship between the United States and Mexico and also focused on thematic issues for the Bureau of Inter-American Affairs including democracy, environment, and human rights. That is how I was drawn into the discussions about Cuba policy.

The Clinton Administration strongly opposed the Helms-Burton Act proposed by Senator Jesse Helms and Congressman Burton. I remember going up to the Congress to the Committee on Foreign Relations of the House of Representatives with a colleague of mine who was in charge of the Caribbean to testify against HelmsBurton-- President Clinton opposed Helms-Burton. The aim of the bill was to codify into law the Cuban embargo, making it impossible for the president to change Cuba policy without an act of Congress. By the way, the Republicans had regained a 
majority in both the Senate and the House in November 1994. Senator Dole was the majority leader in the Senate and Newt Gingrich was the speaker in the House of Representatives. We made it clear that the President is opposed to Helms-Burton bill, that the bill would not bring about positive change in Cuba and, at the same time it would severely affect our allies because several articles of the law, particularly articles $3 \& 4$, placed penalties on other countries that might invest in Cuba.

What happened? Just a few weeks later the Cuban government shot down the planes of an anti-Castro group, Brothers to the Rescue, that flew over Cuba distributing antigovernment leaflets to promote anti-Castro sentiment on the island. The outcry in the US was such that it became impossible for President Clinton to veto the HelmsBurton law, because a two-thirds majority by Congress would have overridden the veto anyway. Title 3 has rarely been invoked because the president can waive it... that's the article that allows companies or people who owned property in Cuba to sue in U.S. courts companies "trafficked in those properties." Title 4 is the one that takes away the visas of executives of companies doing business in Cuba, for instance a Spanish tourism company, or a French bank doing business in Cuba, or something like that. Executives of these companies could be barred from entering the United States, where they might have significant business interests.

Why did the Cubans shoot down the plane and make it more difficult for the first democratic president in 12 years to attempt to change Cuba policy? An important reality in US-Cuba relations is that there has always been a symbiotic relationship between the hardliners in Havana and the hardliners in Miami. In other words they depended and depend on each other, so that in a perverse way top Cuban officials welcomed the Helms-Burton law that codified the embargo. They feared that a liberalization of US policy might lead to greater autonomy for the Cuban people, while the hardliners in Miami felt that that any liberalization would simply strengthen the regime.

There was very little movement after that. When I went into the White House in 1999, to head Latin America policy at the National Security Council in the last two years of the Clinton administration, the President's National Security Adviser asked me to prepare a memorandum outlining the steps the United States could take to change Cuba policy. My office proposed a series of liberalizing measures, which would have taken steps in the direction of the measures that would later be adopted by President Obama. But it became impossible to renew any initiative on Cuba policy because the 2000 presidential election was coming soon, Florida was critical to a democratic victory, and Vice President Albert Gore was running for president. Political advisers at the White House argued against any changes in Cuba policy. As it turned out, Gore got more votes than Bush, but lost Florida by a narrow margin, which might have been greater if the Cuba reforms had been proposed.

Bush was elected president and he went very much in the opposite direction. Under U.S. law, if US citizens wanted to travel to Cuba, they would have to get permission to go by obtaining a special license through the Department of the Treasury. For example, at Georgetown University we had to get an educational license from the Office of Foreign Assets Control, in the department of the Treasury. Although we could send students to study in Cuba in a program closely supervised by Georgetown, the Bush administration restricted travel much more severely than did the Clinton 
Administration, including barring Cuban Americans from visiting their relatives in Cuba except for once in every three years, a severe limitation on many of the Cuban Americans families.

It should be underscored that a hard-liner position on Cuba had proponents in both parties, primarily Cuban American politicians. On the Republican side this included the Diaz Balart brothers, and Congresswoman Ileana Ros Lehtinen (and more recently Senator Marco Rubio) -all from Florida. And on the democratic side, Senator Robert Menendez from the state of New Jersey.

When Obama was elected, Cuba was not immediately a priority. President Obama faced the aftermath of the economic and financial crisis of 2008, as well as the wars in Iraq and Afghanistan. Nevertheless, the administration began to rethink Cuba policy. It was then that I rejoined government as Assistant Secretary, the chief diplomat for the Americas. What was the fundamental rationale that drove for the administration to take-up again the Clinton efforts to change Cuba policy? Very simple-- that the embargo had failed, it had continued to isolate Cuban society, in many ways making it more difficult for Cuba to evolve into a more democratic country as its citizens remained completely dependent on the state for everything, for jobs, for education, for housing... even the vouchers to buy food, that kind of stuff... It was still a totalitarian regime.

The premise was not to partner with the Cuban government, to permit significant commercial investments or anything like that, the whole rationale was to create a stronger people to people engagement, let artists go, let scientists go, let religious people go. As we worked on options, the idea was to see how we could eliminate the individual licenses and create general licenses, which US citizens could use in establishing relationships with Cuban counterparts. This included in some commercial areas-aimed at creating incentives to develop a Cuban the private sector. You could have... l'Association des cosmétiques and you could partner with some organization in the United States, maybe the barbers of South Florida, and they could help you set up your little business, so you could cut hair, that sort of thing.

And remember, even before, under Helms-Burton, the United States could export agricultural goods and medicines to Cuba. In fact, the United States is the largest exporter of food and medicines to Cuba, but investments in other areas such as telecommunications were restricted. Could foreign investments, including US investments, help develop a telecommunication infrastructure that could in turn be used by Cuban citizens to engage with the rest of the world? The rationale continued to be how can we empower citizens, civil society, and by doing so help to encourage the liberalization process.

While we were deliberating internally things were changing in Cuba. The Damas de Blanco movement seeking the liberalization of Cuban political prisoners caught the attention of the world. It was at that time, and since it is in the public record, I can talk about it, that I was called by the Papal Nuncio in Washington and told that the Cuban Cardinal was coming to town and wanted to see me in private. He began our meeting by noting that for the first time in the relationship between the government and the Church in Cuba, the government had asked the Church for help--- rather than simply trying to set down rules. That was in relationship to the Damas de Blanco matter, where the Church initiated a mediating role. He also noted "Castro wanted 
me to come and see you... to note that he was open to a dialogue with the United States."

To my surprise, he also said "Nous aussi, nous avons des Jacobins and des Talibans", "Acuerdate", "Remember, Raul also has his Jacobins and his Taliban." Essentially, he was conveying his concern that the hardliners in Cuba were going to oppose any détente. In fact, I saw that first hand... I later had a private meeting with the Foreign Minister of Cuba and he did not want to hear about any of the proposed steps the US might want to take that could include taking Cuba off the terrorist list, encouraging investment and seeking ways to cooperate-as the US did with Haiti in helping the country after the earthquake. Instead, he insisted on recounting the long history of US Cuba relations and the imperialist attacks on Cuba going back to José Marti's days.

We had agreed to the meeting to discuss possible changes in the relationship, but also because the Cuban government had recently detained an American citizen who travelled to Cuba to engage with religious groups, supplying them with communications equipment. His detention would make it impossible for the Obama Administration to move forward with changes to Cuba policy in his first term.

I said, "look, why did you arrest Alan Gross, you're doing the same thing you did when you shot down the Brothers to the Rescue, the reason why you took Gross is that you really don't want liberalization to take place". By capturing Gross, I think the hardliners in Cuba were essentially sending a signal that they didn't want liberalization, they didn't want things to change. You must change on our terms, which are "lift the embargo but let's continue to control Cuban society", no democracy, and no competitive elections, none of that stuff.

And there was also the Oswaldo Paya tragedy, as well; he had a lot of supporters.

Ironically the hardliners in Havana didn't like him at all because Oswaldo Paya kept saying that change could come within the framework of the existing Cuban constitution. That was what the Varela project was all about, gathering signatures, so that people could now hold better elections. The hardliners in Miami did not like that because they thought he was too accommodating to the regime.

Despite that, in 2011, the Obama Administration did introduce some important changes in Cuba policy in it first term, which paved the wave for the secret negotiations with Cuba that took place when the President was reelected. (I left the Obama Administration in August of 2011, to return to my duties at Georgetown.) In fact, one of the key people involved in those negotiations was someone who had worked closely with me when I was Assistant Secretary. I am referring to Ricardo Zuñiga, a career foreign service officer who had been the acting director of the office of Cuban affairs when I was at the State Department. He had drafted ideas that were presented to Secretary Clinton and then to the White House for that were the bases of the first group of changes that were implemented by the administration in the first term.

Zuñiga was appointed to the National Security Council in the Second Obama Administration where he was asked by Ben Rhodes, who was the Deputy National Security Advisor, to help negotiate directly with the Cubans, joining Rhodes in those talks. I am convinced that one of the reasons the Cubans now expressed interest in the conversations and helped resolve the detention of the American in Cuba, was the 
increasingly critical situation of the Cuban economy, particularly after Venezuelan subsidies began to decline.

And one of the things that are interesting is that the Obama administration went further than the Cubans expected, insisting that diplomatic relations also be reestablished. But, the Cubans really did not want that, they just wanted the United States to lift the embargo so that they could overcome their economic difficulties. They were taken by surprise when the administration insisted, and at first, they opposed it very strongly, relenting when the Administration made clear that reestablishing diplomatic relations was an important part of a possible agreement. Remember... that many hardliners in Cuba continued and continue until today to oppose normalization... they fear very much an independent, a more self-sufficient civil society because they have controlled it so thoroughly all these years.

Did the opening, suddenly announced in December 2014, surprise you or did you think that it was just the result of so many years of underground work?

These things don't happen overnight. There's several explanations for why perhaps the Cubans were more willing to do this, one of them was the overdependence on Venezuelan oil, and the continued weakness of the Cuban economy, and the awareness that ... I didn't mean to suggest that I think that Raul Castro was somebody who wanted to essentially have the credit of elections, but Raul Castro wanted perestroika, he didn't want glasnost, he wanted perestroika, an economic opening and not necessarily a political opening.

The fear of course, is that for the hardliners, if there was perestroika there would be too much of a pressure for them to have glasnost too, which is the debate, by the way, that took place in Mexico as well, when the PRI began to liberalize the economy, the pressure that Salinas was under was that you can't just move towards free trade with the US without necessarily thinking that there would also be pressure to hold more competitive elections.

Recently a press release by Republicans spoke of the " Cuban nefarious activities in Venezuela". How do you view a possible impact of current developments in Venezuela on Cuba?

I think in some ways there was a strong codependence there. On the one hand, Chavez welcomed the advice and the work of all the Cuban doctors in Venezuela, one of the key exports of Cuba. They were very successful in helping the government build a strong allegiance from some of the lowest sectors of society and that included health care. Thanks to Cuban doctors, in exchange for oil. The Cuban economy essentially could survive this very difficult period because of the subsidies they got from Venezuelan oil. Petrocaribe was important for Cuba at the time when the economy was really in trouble. And of course, the collapse of Venezuela has become very problematic for Cuba. Some people don't understand why the Cubans seem to be supportive of Maduro but I'm not quite sure they fully are... Actually I suspect there are a lot of differences of opinions in Havana on how to handle the Venezuela crisis.

How do you foresee the future of the opening between the United States and Cuba?

You know, there's no question that because of the direct intervention of people like Rubio, the speech that Trump gave in Miami and then his statements, essentially pointing to reinstating some of the measures that President Bush had taken was very much motivated by Florida politics. Remember that he was very, very critical of 
President Trump's appointment of Rex Tillerson as Secretary of State; there was strong influence from Cuban Americans on that decision too.

Now, if you look at the changes, there's two things to underscore: so far, they have not gone back to the very restrictive policies of the second Bush administration and it was notable that President Trump did waive Title 3 (the president can waive it every 6 months), in part because of the criticism of European allies about the extraterritorial reach of U.S. legislation. But at the same time there's a lot of uncertainty about administration policy. Its hardline rhetoric is more apparent than real substantive changes. And yet individuals and companies don't know what to do, should we invest in Cuba, what's coming next. This is due to the lack of clarity on the part of the Administration, the disorganization in the White House, the frequent policy contradictions, and the lack of leadership in some of the key agencies like the State Department.

When you read Human rights organizations reports, they're critical of the condition of human rights in Cuba, it seems that more people have been arrested, precisely since December 2014, so do you think this fuels the opposition of those who criticize Obama's policies and fuels President Trump's policies?

I think there is simply no question that the Castro regime has been very hard on dissidents in Cuba. The human rights advocates are correct in saying that this is a regime that continues to bar free expression, bar activities ... they even go after artists ... but the question though is whether the previous policy of isolating Cuba, with the embargo, had worked in terms of changing that dynamic?

Quite the contrary, in fact, it made it much easier for the regime to go after.... in fact, one of the things that is interesting about it is... when President Obama took these steps and reestablished diplomatic relations and so on and then when artists and others in Cuba began to express their views more freely, and they were arrested, there was much more criticism not only from the United States but also from eventhe left in Latin America, that became very disillusioned with Cuba. They've lost some ground, I think, particularly with the younger people.

So, what can be said to the human rights people: not to restore the same sort of draconian measures on Cuba, which in fact allowed the Cuban regime to be even more successful in pushing back on human rights. And the cuban regime is not necessarily going to change its policy. In other words, if we ... Let's put it this way...in some ways, the people to people strategy is a strategy to force the Cuban government to liberalize. This is not a situation where you ask this Cuban government, "please liberalize or otherwise we're not going to work with you". On the contrary, "look, we're going to take some steps that will make it more difficult for you to continue with this regime ... because we know that many of you don't want changes".

How do you anticipate future developments after Raul Castro leaves the presidency in February 2018?

Ironically, I do agree with the Cuban Cardinal's statement about Castro. I don't necessarily see Raul Castro as representative of the hardest line sector of the Cuban political system. Again, he wanted perestroika, without necessarily wanting glasnost. However, with Castro out in the near future, I worry about some of the replacement leaders who have reached positions of power under this regime and don't have clear incentives to change that. I'm not sure that in the short-term Raul Castro's stepping from the stage is necessarily going to lead to significant liberalization, I think it is 
going to take some time. A lot will depend on how the replacement people see the need for transformation ... Let's put it this way, if you find more Gorbachevs or Jaruzelskis that are prepared to work with some of the incipient democratic forces in Cuba, maybe you'll see that. The international community, including the United States, should help to encourage that process.

So, it is a big question mark...

It is a question mark but the issue is, returning to the draconian policies of the past would probably play in the hands of those hardliners who don't want change. So, I would strongly argue for a continuation of policies of engagement and empowerment of Cuban society.

This sounds like a perfect conclusion. So many thanks for your time and for sharing your memories and your insight with us.

\section{AUTEUR}

\section{ISABELLE VAGNOUX}

Aix Marseille Univ, LERMA, Aix-en-Provence, France

Rédactrice-en-chef d'IdeAs, Idées d'Amérique, Isabelle Vagnoux est professeur des Universités à Aix-Marseille, spécialiste de politique étrangère américaine et des relations avec l'Amérique latine. Elle co-dirige à Aix l'Observatoire des relations extérieures du monde anglophone (OREMA) au sein du LERMA (EA 853). isabelle.vagnoux@univ-amu.fr 